\title{
Terceirização no Brasil: velhos dilemas e a necessidade de uma ordem mais includente
}

\author{
MÁRCIA dA SILVA COSTA \\ Universidade federal da Paraíba / Departamento de Administração, JoÃo Pessoa - PB, Brasil
}

\begin{abstract}
Resumo
Discussão sobre o fenômeno da subcontratação nas organizações contemporâneas. Tal fenômeno é aqui entendido como parte do processo mais amplo de flexibilização das instituições sociais e do trabalho que acompanhou o desmonte do fordismo e tem sido responsável pela fragmentação e precarização dos mercados de trabalho em todos os países industrializados. Adota-se aqui a perspectiva de análise na qual são discutidas as implicações da terceirização para os trabalhadores. À luz das teses da crise da sociedade salarial e da acumulação flexível, cuja referência é encontrada no pensamento da escola da regulação fordista, argumenta-se que a subcontratação, mais conhecida no Brasil como terceirização, reforça as relações de dominação e o controle social sobre a força de trabalho, rebaixando ou retirando direitos historicamente conquistados. Esse processo tem sido muito mais pernicioso em sociedades de democracia recente, como a brasileira, nas quais as novas práticas de flexibilização do trabalho contribuíram para fragilizar, ainda mais, a estrutura do mercado de trabalho, historicamente marcada pelos baixos salários, pela excessiva instabilidade do vínculo empregatício, pela baixa qualificação dos seus trabalhadores, pela fraca organização coletiva, pelos parcos direitos cidadãos. A despeito dos avanços nos indicadores do emprego e da renda na última década no país, a subcontratação tem se disseminado, o que reitera esse padrão predatório de relações de trabalho.
\end{abstract}

Palavras-Chave: Subcontratação. Trabalho precário. Perda de direitos.

\section{Outsourcing in Brazil: old dilemmas and the need for a more including order}

\begin{abstract}
This article discusses outsourcing in contemporary organizations. Outsourcing is understood here as part of a broader process of flexibility of labor and of social institutions, which followed the decline of Fordism. This process has been responsible for an increase of fragmented and precarious labor markets in all industrialized countries. The analytical perspective adopted in this article discusses the implications of outsourcing for workers. In light of the thesis of wage society crisis and flexible accumulation, whose reference is found in the school of Fordist regulation, this article argues that outsourcing reinforces the relations of domination and social control over the workforce, which lowers or removes historically achieved rights. This process has been much more pernicious in newly democratic societies such as Brazil, where new flexible work practices contribute to weakening the structure of the labor market, historically marked by low wages, excessive employment instability, low skill workers, weak collective organization, and lack of social rights. Despite advances in employment and income indicators during the last decade, outsourcing has become widespread reiterating this predatory pattern of labor relations.
\end{abstract}

Keywords: Outsourcing. Precarious work. Loss of rights.

\section{Subcontratación en Brasil: viejos dilemas y la necesidad de un orden más inclusivo}

\section{Resumen}

Debate sobre el fenómeno de la subcontratación en las organizaciones contemporáneas. Este fenómeno se entiende aquí como parte de un proceso más amplio de flexibilización de las instituciones sociales y del trabajo, que siguió el desmantelamiento del fordismo y ha sido responsable por la fragmentación y precarización de los mercados de trabajo en todos los países industrializados. Se ha adoptado aquí la perspectiva de análisis en el que se discuten las implicaciones de la subcontratación para los trabajadores. A la luz de las tesis de la crisis de la sociedad salarial y de la acumulación flexible, cuya referencia se encuentra en el pensamiento de la escuela de regulación fordista, se argumenta que la subcontratación refuerza las relaciones de dominación y control social sobre la fuerza de trabajo, rebajando o eliminando derechos históricamente conquistados. Este proceso ha sido mucho más pernicioso en las sociedades democráticas recientes, como Brasil, donde las nuevas prácticas de flexibilización del trabajo han contribuido a debilitar aún más la estructura del mercado de trabajo, históricamente caracterizada por bajos salarios, excesiva inestabilidad del vínculo laboral, baja calificación de sus trabajadores, débil organización colectiva, y derechos ciudadanos. A pesar de los avances en los indicadores de empleo e ingresos en la última década en el país, la subcontratación se ha difundido, lo que reitera este modelo depredador de las relaciones laborales.

Palabras clave: Subcontratación. Trabajo precario. Pérdida de derechos. 


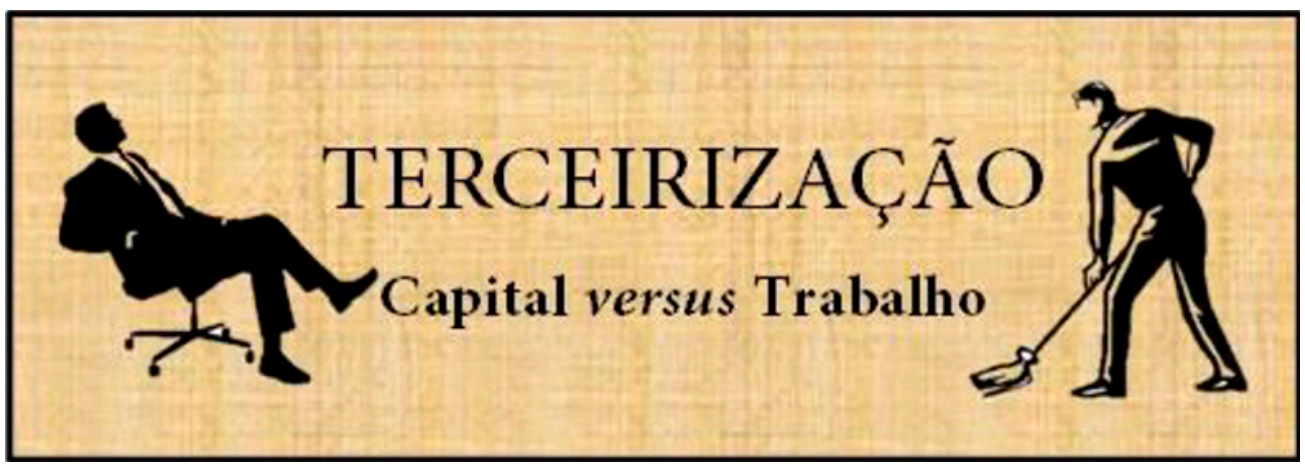

\section{INTRODUÇÃO}

Muito já se escreveu sobre a terceirização. Os que buscam incessantemente a elevação dos níveis de produtividade e competitividade das empresas e da economia defenderam-na com garra e argumentos persuasivos, a exemplo dos manuais de Administração (GIOSA, 1997; SARATT, SILVEIRA e MORAES, 2008;) e de referenciados formadores de opinião na área econômica do país, como Pastore (2006; 2015). Para eles, em termos gerais, a terceirização constitui um poderoso instrumento de gestão que permite às organizações (públicas ou privadas) especializarem-se nas áreas centrais de sua atividade produtiva, reduzindo custos e fomentando o crescimento econômico e o emprego, ao passo em que são desenvolvidas relações de parceria comprometidas com o aperfeiçoamento de produtos e serviços. Legitimadas por esse discurso, que teve amparo legal, as empresas encontraram campo fértil para pôr em marcha iniciativas diversas de subcontratação, contemplando mesmo atividades consideradas centrais dentre as etapas de suas atividades produtivas. Tem-se, assim, a linha de argumentação positiva e, no dizer de seus defensores, propugnadora do que existe de mais moderno em termos de práticas de administração.

Existe, no entanto, outra corrente de pensamento, comprometida com o esclarecimento das implicações sociais deste fenômeno, para a qual a terceirização constitui, na verdade, um mecanismo por meio do qual as empresas podem almejar ganhos de produtividade e competitividade, reduzindo os custos do trabalho ao se eximirem da responsabilidade de gerir e assalariar diretamente o trabalhador segundo ditam as normas legais e negociadas, que tradicionalmente protegeram as relações de trabalho. Para essa corrente, a terceirização, como uma forma de subcontratação, é produto de um processo mais amplo de desverticalização e desterritorialização da atividade produtiva, até então centrada na grande empresa, e que tem, dentre as suas principais consequências, o desemprego e a fragmentação da força de trabalho acarretando o enfraquecimento político desta e de sua ação coletiva. Esse retraimento do espaço político em que se disputa a distribuição da riqueza produzida é responsável, portanto, por um fenômeno sistêmico de individualização das relações de trabalho, de desvalorização salarial, de precarização das condições laborais, de má distribuição de renda. Numa análise mais profunda, as implicações da terceirização para os trabalhadores representam as manifestações mais concretas de um modo de organização da produção e do trabalho cuja lógica e nexo permanece sendo, prioritariamente, a acumulação via exploração.

No Brasil, comumente tratada pela expressão "terceirização", a subcontratação alastrou-se de tal maneira e num sentido a questionar o ordenamento legal da regulamentação do trabalho no país, que o próprio Tribunal Superior do Trabalho (TST) convocou, em outubro de 2011, de forma inédita na história das deliberações desta instância jurídica, um debate nacional sobre as implicações da terceirização, extrapolando o tratamento estritamente jurídico dado ao tema. Essa louvável iniciativa dá mostra da complexidade e relevância da subcontratação no país, responsável por cerca de cinco mil disputas trabalhistas

* Fonte da imagem: Elaborado pela autora. 
para as quais inexiste uma lei geral disciplinando seus limites (AMATO, 2011). A realização da audiência pública visou, entre outros objetivos, ressaltar a importância do diálogo com a sociedade e dele obter subsídios para o julgamento de casos de importante repercussão social, legitimando as decisões do TST. Os resultados desse debate deverão, inclusive, alimentar a discussão de pelo menos três projetos de lei sobre a matéria em tramitação na Câmara dos Deputados.

A presente reflexão se desdobra no marco social, econômico e político dessa discussão. O esforço de ressaltar a lógica destrutiva (de valores, de relações sociais, de identidades, de dignidade de vida) à qual ela está ligada constitui, certamente, tarefa de fôlego e por demais importante num momento em que se asseveram as contradições do sistema capitalista de produção no seio de sua maior crise desde a década de 1930. Esse é, portanto, o caminho trilhado neste artigo para trazer o tema à tona no espaço do debate social.

A discussão se dá não da perspectiva da apologia de uma prática de gestão empresarial, tampouco a perspectiva de análise aqui adotada é a jurídica, mas necessariamente a que alimenta os fundamentos éticos e democráticos das deliberações normativas. Ou seja, discutem-se as implicações da terceirização para os trabalhadores, para o projeto da socialdemocracia de universalização dos direitos cidadãos e para a ordem mesma do sistema capitalista de produção. Na linha da velha abordagem marxista, o fenômeno da subcontratação reforça as relações de dominação e o controle social sobre a força de trabalho, ataca as instituições que, a despeito dos sacrifícios dos ideais libertários, permitiram que essas relações de dominação se pautassem em reciprocidade e encontrassem legitimidade entre os próprios dominados. Suas consequências (desemprego, subemprego, pobreza, desigualdade social) representam manifestações de um conflito estrutural básico, portanto, de crise permanente, cuja solução só pode ser alcançada, e reiteradamente negociada, por meio da abertura política dos espaços em que ocorre a disputa pela apropriação da riqueza produzida. A terceirização representa, contraditoriamente, um fechamento desses espaços políticos, e esse é, portanto, o argumento central que norteia a reflexão aqui apresentada.

Trata-se, assim, de discutir a questão, num primeiro momento, procurando contextualizá-la no conjunto mais amplo das transformações contemporâneas que o sistema capitalista vem sofrendo, evidentemente centrando a reflexão sobre as implicações para o mundo do trabalho. Em linhas gerais, essa reflexão é tributária, como vem sendo paradigmático no debate acadêmico, das teses da acumulação flexível (BOYER, 1995; HARVEY, 1989) e da crise da sociedade salarial (CASTEL, 2005), cuja referência é encontrada no pensamento da escola da regulação fordista. As noções de globalização, reestruturação produtiva, neoliberalismo estão no centro dessas transformações, remetendo a novas e não tão novas formas de organização do trabalho e de relações sociais organizadas em torno da ideologia do mercado.

Mas essas novas formas de organização do processo produtivo e de relações sociais, embora imbricadas em um complexo conjunto de interações e interdependências globais, precisam ser entendidas por meio de suas manifestações em realidades sociais concretas, e seu entendimento não pode prescindir de uma análise em que minimamente sejam consideradas as especificidades políticas e institucionais estabelecidas no processo histórico. Assim, num segundo momento deste ensaio, busca-se discutir o fenômeno da subcontratação considerando os determinantes estruturais que permitiram sua disseminação na economia brasileira, cuja principal consequência para a classe trabalhadora foi uma ainda maior fragmentação e redução de seu poder de barganha, o que permitiu o fortalecimento do poder discricionário das gerências, legitimando e recrudescendo a adoção de práticas autoritárias que flexibilizam, desvalorizam, vulnerabilizam as relações de trabalho. 0 ponto de chegada neste artigo é trazer para o debate os determinantes centrais desse processo, que apresenta sua face mais cruel na elevação do desemprego e da taxa de precarização dos regimes de emprego (subemprego,informalidade), que corroboram o vergonhoso título que o país ostenta, o de ser um dos que distribuem mais desigualmente sua riqueza.

\section{O PADRÃO DE ASSALARIAMENTO NO PÓS-GUERRA: EMPREGO COMO NORMA SOCIAL}

Todas as análises das transformações estruturais por que têm passado as economias capitalistas contemporâneas apontam para a crise de um padrão de desenvolvimento construído, a partir da década de 1930, como tábua de salvação econômica: o Estado de bem-estar que se consolida no pós-guerra sob a hegemonia norte-americana por meio das políticas keynesianas de reconstrução das economias nacionais. Esse novo padrão de desenvolvimento, que impunha um marco regulador à livre competição de mercado, trazia em suas linhas mestras a proposta de conciliar crescimento econômico e desenvolvimento 
social, o que, até então, as nações tinham relegado ao livre arbítrio das relações na esfera privada entre capitalistas e entre estes e seus trabalhadores.

Projeto da socialdemocracia europeia, a intervenção do Estado na economia ocorreu como resultado da pressão política dos atores sociais subordinados na ordem dominante por meio de sua organização coletiva em sindicatos e partidos políticos. 0 padrão de estruturação do assalariamento, que os teóricos da escola da regulação francesa chamaram de regime de regulação fordista, tinha como princípio a regulação dos conflitos e interesses de classe por meio da intervenção do Estado na garantia do direito de representação e de proteção social dos trabalhadores.

O pacto social do pós-guerra foi forjado mais ou menos pela seguinte barganha: trabalhadores aceitavam o comando e o controle autoritário da gerência científica (abandonando seus projetos de controle socialista da produção e reduzindo sua crítica à organização do trabalho), pelo que se comprometiam com a produtividade em troca da estabilidade no emprego e aumentos reais de salários. O Estado, por sua vez, como guardião desse compromisso, institucionalizava os sindicatos, legitimando a negociação coletiva e instituindo normas gerais de contratação (duração da jornada, salário mínimo, proteção contra demissões imotivadas, etc.) e de proteção social. Ao lado dos incentivos à demanda agregada com gastos em infraestrutura, o Estado também passava a promover uma massiva distribuição de renda via políticas públicas de acesso à saúde, educação, provisão de pensões, seguro desemprego, etc. Por esses mecanismos, a redistribuição da riqueza produzida coletivamente passava a ser objeto de disputa política, seja diretamente, na esfera produtiva, mediante negociação coletiva, cujo foco de disputa central era o repasse da produtividade para os salários; seja na esfera dos projetos de governo, no âmbito das políticas sociais, que garantiam uma base mínima para a reprodução da força de trabalho fora da esfera do mercado ${ }^{1}$ ().

Como sistema macropolítico, o regime de regulação fordista estava associado ao modelo de organização da produção e do trabalho que possibilitou deslanchar, com a legitimação das classes trabalhadoras, a própria expansão do capital oligopolista. Esse regime se fundava numa tríade de interesses bem definidos: produtividade-renda-consumo, e tinha por substrato um compromisso político fundamental: o emprego. Não o emprego enquanto concepção economicista de uma atividade produtiva à qual se retribui com uma compensação monetária; não o emprego ou o trabalho (que aqui aparecem como sinônimos) visto como mera mercadoria, mas o emprego em sua dimensão mais ampla, imbuído de uma normatividade social, portanto, produto de lutas e conflitos sociais; produto da política e não de um determinismo de mercado (PRIETO, 1999b).

No nível mais micro de organização das estratégias e estruturas de produção, a divisão do trabalho aparece como base técnica e social dominante. O modelo fordista de produção se centra na fragmentação do processo de trabalho em tarefas simples e repetitivas, que exigem pouca qualificação e iniciativa do trabalhador; e nasce associado à produção verticalizada, em larga escala, de produtos padronizados e para o consumo em massa. Essa organização produtiva verticalizada, tendo por base a extrema especialização do trabalho, tornou-se a fonte mais objetiva da concentração de grandes contingentes de trabalhadores sob um mesmo teto, condições de trabalho e direção. Isso permitiu a sua organização coletiva e, com ela, a mobilização para a ação política responsável pela construção de uma normatividade para as relações sociais e de trabalho.

A concentração oligopolista do grande capital e a organização verticalizada do processo produtivo constituíram-se, assim, no determinante histórico que permitiu o fortalecimento dos sindicatos e de sua capacidade para negociar, de forma mais ou menos centralizada e sob uma lógica coletiva e de tendência homogeneizadora, regras de contratação e uso do trabaIho (salários, produtividade, jornada, igualdade de pagamento para trabalhos similares, carreira, ritmos de produção, entre outros). De igual maneira, por meio de vínculos a partidos políticos de esquerda, pressionando a alternância de poder em todas as regiões do capitalismo desenvolvido, os trabalhadores conquistaram participação em projetos de política econômica e social do Estado que primavam por uma dinâmica sempre crescente de seguridade social e cidadania. Não obstante, ainda que seja possível falar de convergências entre padrões institucionais de regulação econômica e social (todos os países centrais lograram alcançar níveis universais de emprego regulado), a democracia na produção e o Estado de bem-estar foram desenvolvidos de maneira desigual e diferenciada no tempo, na extensão e na intensidade, em cada contexto nacional, razão

\footnotetext{
${ }^{1}$ Um princípio básico das políticas sociais, sobretudo às relacionadas à seguridade, é o de garantir um meio de sobrevivência para o trabalhador nos períodos em que ele não pode trabalhar ou não encontra emprego. Essas políticas foram tanto mais universais e de elevado padrão quanto mais os movimentos dos trabalhadores foram bem sucedidos em abrir espaços na arena política e construir colisões com as outras classes, como foi o caso das sociais democracias do norte da Europa. Ver, entre outros, Esping-Andersen, 1990; Boyer, 1995; Castel, 2005.
} 
mesmo das diferenças culturais e da própria história do conflito político em cada formação social. Ver, por exemplo, EspingAndersen (1990), Przeworski (1985).

Esse padrão de assalariamento ou de regulação social conquistado pela ação política dos trabalhadores foi vertido, então, no mecanismo estruturador central das relações de trabalho nas sociedades capitalistas modernas: o emprego regulado social e politicamente; não pela exclusiva lógica das liberdades de mercado, mas pela interferência política dos sindicatos (a negociação coletiva), das legislações trabalhistas e da subvenção do Estado à cidadania. Por esse caminho, o capitalismo, que por origem e natureza encontra na competição destruidora do mercado a sua lógica fundante, articulou crescimento econômico e coesão social. Com ele, os indivíduos vendedores de força de trabalho, destituídos dos meios de produção, passaram a acessar institutos/direitos de uma proteção social mínima contra as investidas desumanizantes da racionale do mercado. Sob a condição das instituições do assalariamento, da sociedade salarial na reflexão de Castel (2005), quando já tinham sido rompidos os vínculos tradicionais da solidariedade e da proteção primária, o indivíduo passava a ocupar um lugar na sociedade e participar de suas redes de sociabilidade e proteção.

É essa a ideia que está por trás da importância de se pensar o emprego como norma social. O fio condutor do argumento de Castel é de que a sociedade salarial, com suas instituições reguladoras, embora fundada na diferença, numa estrutura de recursos e de poder (posição) desigual, conseguiu a proeza de integrar o todo social por meio da proteção veiculada pelas intervenções do Estado e do trabalho na economia (no mercado). O arranjo produtivo e institucional que disseminou o assalariamento como padrão dominante de regulação das relações de trabalho constituiu-se, assim, no cimento que unia e tornava interdependente o conjunto da sociedade, que vinculava institucionalmente o indivíduo a algum grupo social e que Ihe proporcionava, além de seu meio de vida, um pertencimento, uma identificação (de classe, sobretudo), tendo por base mesmo sua posição na estrutura produtiva e o status que a renda e o padrão de consumo lhe conferiam. É esse mecanismo central que as novas formas de organização do processo produtivo vêm destruindo, dentre às quais a subcontratação ocupa lugar proeminente. Observe-se como se vem processando essa nova realidade.

\section{ACUMULAÇÃO FLEXÍVEL: A INSTABILIDADE E A INSEGURANÇA COMO NORMA}

Se no contexto macrossocial do fordismo, os conflitos diretos entre capital e trabalho foram arrefecidos pelos ganhos de produtividade da produção em larga escala e pela elevação do padrão de consumo de um trabalhador afluente (GOLDTHORPE, 1968), no interior do processo produtivo eles seguiram latentes, mas fortes e contínuos, reflexo mesmo do caráter autoritário, alienante, destituído de sentido com que a gerência organizava o trabalho. Por outras palavras, a paz keynesiana e beveridgiana não eliminou o ânimo capitalista de se independer do trabalho vivo e ajustar as bases técnicas da produção aos determinantes do processo de valorização. A natural propensão do capital de revolucionar tecnologia, métodos de organização do trabalho e relações sociais atuou no sentido de debelar aqueles conflitos e obstar as demandas dos trabalhadores, retomando as rédeas para o livre desembaraço das forças do mercado².

Pressionado por um ambiente acirradamente mais competitivo desde as duas grandes crises do petróleo na década de 1970 (que fez reduzir a taxa de acumulação), o grande capital passava a veicular a ideia de que a rigidez institucional dos contratos coletivos de trabalho e os gastos sociais do Estado impediam o livre funcionamento da economia. Disseminava-se por toda parte, e por meio de governos dos mais diversos matizes políticos, a ideologia neoliberal na defesa de relações de troca mais flexíveis e autorreguladas pelo mercado. No concreto das coisas, a reestruturação produtiva levada a cabo de forma sistêmica em todas as economias, ainda que em momentos e intensidade diferentes, nocauteou o movimento ascendente de conquistas sociais e trabalhistas que marcou o conflito de classe desde a década de 1930.

O desmonte das instituições da sociedade salarial (fordista) passava a se dar por duas grandes vias inter-relacionadas: pela via da desverticalização produtiva, que gerou muito desemprego; e pela via da desregulamentação do mercado de trabaIho, responsável pela expansão dos empregos sob condições e salários inferiores ao padrão até então prevalecente. Baixo

\footnotetext{
${ }^{2}$ As inquietações sociais na Europa no final dos anos 1960 (maio de 1968, na França; outono quente de 1969, na Itália, simbolizando as manifestações mais subversivas) representaram o ponto culminante da resistência à racionalização do trabalho e um dos impulsionadores da reestruturação capitalista que se desencadearia a partir de então.
} 
crescimento e instabilidade econômica, elevado desemprego e enfraquecimento dos sindicatos permitiram que o discurso político sobre a flexibilidade dos mercados de trabalho se tornasse dominante e legitimasse reformas nas instituições do trabalho e da proteção social.

No campo das ideias, pois, a flexibilidade de todos os recursos e instituições passava a orientar as práticas de empresas e governos, um pensamento que se autoproclamava como o único capaz de fazer as economias retomarem a estabilidade do crescimento. Conceitos como o de capitalismo globalizado ou o de acumulação flexível entravam em cena na tentativa de caracterizar esse novo momento da trajetória das forças produtivas. Seu curso era marcado, sobretudo, pela elevada exclusão, pela desigualdade, pela instabilidade e pela precariedade dos regimes de emprego.

Ao passo que o capitalismo flexível se dotava de todos os instrumentos (tecnológicos, institucionais, ideológicos) para coordenar suas atividades em âmbito global, o trabalho se individualizava, se fragmentava, se enfraquecia possibilitando o avanço das iniciativas no campo da flexibilização e da retirada de direitos. O movimento que pregava (e concretizava) a abertura das barreiras comerciais era o mesmo que fechava ou transferia unidades produtivas, sobretudo suas etapas mais taylorizadas, de suas bases de origem para regiões e países onde é grande a carência de investimentos, a força de trabalho é extremamente abundante e as instituições democráticas, se existem, são mais fracas. Mais que isso, o capitalismo flexível e global de finais do século XX não é o mesmo capitalismo produtivo, industrial, assentado em fundamentos econômicos de longo prazo, que gera emprego e cumpre uma função social. Afrouxadas as rédeas políticas e sociais que de alguma forma impuseram limites à sua ética individualista e autointeressada, despontava com mais força um capitalismo essencialmente financeiro, especulativo, volátil, de lucros imediatos, assentado em relações sociais efêmeras e descartáveis (BOLTANSKI e CHIAPELLO, 2009; BOYER, 1995; CASTELLS, 2001; HARVEY, 1989; SENNETT, 1999).

A globalização da economia, fenômeno que acompanha a propagação do capitalismo flexível, tem seu caráter mais contundente na quebra das barreiras alfandegárias e na desregulamentação dos mercados financeiros e de capitais. Sob um âmbito de atuação transnacional e a lógica da liquidez imediata, as corporações põem em xeque a capacidade política de os Estados nacionais regularem a economia e negociarem regras de seu interesse para reter investimentos de longo prazo que gerem empregos e promovam o desenvolvimento social. Conforme esclareceu Chesnais (1996), a radical liberalização financeira pode ser considerada um dos determinantes centrais dos processos de racionalização produtiva (novas tecnologias, subcontratação, flexibilização do trabalho, baixo investimento etc.).

No âmbito das economias nacionais, o neoliberalismo anglo-saxão apontou a saída da crise pela via de um modelo de gestão flexível e desregulamentado que logo se espalharia para as outras economias com a promessa de geração das "novas jazidas de empregos". Onde elas medraram, não sem sofrer os refluxos da instabilidade econômica, foram marcadas pela pecha do trabalho inseguro e barato - denominado emprego atípico pelos analistas, veio a se tornar cada vez mais a regra. Em praticamente todas as economias industrializadas as mudanças foram e têm sido focadas na desregulamentação dos mercados de trabalho e no desmonte ou redução das políticas de seguridade social, os dois pilares centrais de sustentação do fordismo. Essas iniciativas puseram em xeque o padrão de assalariamento consolidado no pós-guerra: o emprego regular, de mais longa duração, para um mesmo empregador, assistido pelas conquistas da barganha coletiva e por legislações trabalhistas e políticas públicas atinentes às metas de pleno emprego e de redistribuição social. Esse regime de emprego, então dominante, passava a ceder, cada vez mais, lugar à disseminação de regimes diversos e mais flexíveis, mas que têm em comum o fato de serem empregos instáveis, de curta duração, de baixos salários e minguadas contribuições sociais, de fraca capacidade de organização coletiva, disponibilizados para as empresas ao sabor de suas demandas e sob um tipo de gestão fortemente refratário a compromissos.

Por sua vez, no âmbito das estratégias das firmas, a típica empresa fordista é estruturalmente desmontada com o auxílio das novas tecnologias da informação e por uma lógica de desterritorialização para qualquer parte do globo onde se encontrem vantagens competitivas, sem importar a que custo social ou ecológico. A estratégia, esbravejada nas décadas de 1980 e 90 por acadêmicos e gurus/consultores da administração e da economia, pode ser assim resumida: desverticalizar e subcontratar. O seu reverso: desemprego e desestruturação social nos locais de origem da velha organização fordista, exploração de trabalho barato e coberto por parcos direitos nas novas frentes de produção abertas ${ }^{3}$.

${ }^{3}$ Todos sabem: a China se transformou no celeiro industrial do mundo. O que pouco se discute é que seus trabalhadores, destituídos dos mais básicos direitos políticos (o de organização coletiva, por exemplo, que a OIT recomenda há pelo menos cinco décadas), são explorados a salários médios de US\$ 30 ao mês. 
Concomitante a este processo e em boa parte como produto das políticas de subcontratação, deu-se outra grande mudança: o grosso do emprego se desloca para o setor de serviços, e aqui cabe destacar, como o fez Castells (2001), que não se tratou, necessariamente, de se registrar um predomínio desse setor na geração da riqueza. O peso da economia dos países centrais continua derivando da produção industrial, embora esta se encontre espalhada pelo mundo sob a égide da nova divisão internacional do trabalho. A subcontratação provocou o surgimento de uma miríade de médias e pequenas empresas que passaram a fornecer produtos/serviços para as grandes indústrias desverticalizadas; um processo que também está imbuído na expansão do setor de serviços, e que alguns autores entendem como de terciarização da economia. Mas essa expansão se dá por uma lógica de controle financeiro, tecnológico e comercial das grandes empresas. Foi, portanto, para essa miríade de médias e, sobretudo, de pequenas empresas que se deslocou o emprego, embora jamais de forma a absorver proporcionalmente os trabalhadores descartados pelos postos de trabalho queimados na grande indústria reestruturada tecnológica e organizacionalmente.

E qual era a vantagem de subcontratar? O fato de as pequenas e médias empresas garantirem a flexibilidade produtiva e o ajuste às flutuações de mercado de suas contratantes. Isso é possível porque elas podem contar com a utilização da abundante força de trabalho que compõe o que se convencionou chamar, nos países desenvolvidos, de mercado de trabalho secundário, no qual predomina a acirradíssima competição entre trabalhadores de baixa ou nenhuma qualificação, altamente propensos a aceitar qualquer oferta de trabalho. Nesse segmento, tradicionalmente mais difícil de organizar, os sindicatos sempre tiveram baixa ou nenhuma influência.

O emprego em massa - que permitiu a união de trabalhadores em uma mesma unidade econômica, a construção de uma identidade de classe e de interesses e a sua organização coletiva - é, segundo a lógica da acumulação flexível: 1) reduzido ao mínimo possível, não apenas pela via tecnológica da automação dos processos produtivos, que eleva, sobremaneira, a produtividade com cada vez menos trabalhadores; mas também, e talvez mais centralmente, pela via das mudanças organizacionais, bem ao molde da filosofia da gestão toyotista, por meio da qual a produtividade é extraída da intensificação do trabalho em empresas excessivamente enxutas; 2) fragmentado entre contingentes diferenciados de trabalhadores, impossibilitados de se organizarem coletivamente, e que trabalham com status ou direitos inferiores.

A subcontratação fez proliferar a atividade produtiva entre médias e pequenas firmas de mais baixo poder de capitalização (poder econômico) e onde é consideravelmente mais difícil a sindicalização. Seu impacto mais significativo se manifestou numa maior segmentação do mercado de trabalho e no enfraquecimento do poder da barganha coletiva. Como estratégia corporativa, ela tem, portanto, uma finalidade econômica deliberada: reduzir os custos produtivos, essencialmente os custos do trabalho, dotando as empresas de maior flexibilidade para o ajuste às oscilações da demanda; e um fim político não menos deliberado: o controle sobre a força de trabalho. Não é a estratégia única, mas, como argumentaram Thébaud-Mony e Druck (2007), assume centralidade no contexto de flexibilização e precarização do trabalho da era da acumulação flexível. No entanto, e este é um aspecto a se ressaltar, a subcontratação é, antes de tudo, produto de um processo mais amplo de reprivatização ou despolitização das relações de trabalho. Ela se expande como prática empresarial, e também de governos, no seio de um contexto de maior liberalidade econômica decorrente da retração da capacidade de os trabalhadores representarem seus interesses nas instâncias políticas onde tradicionalmente são travadas as disputas pela apropriação da riqueza produzida: a negociação coletiva e os parlamentos.

Os sindicatos tiveram seu poder de organização e mobilização reduzido, deixando o campo de luta mais aberto para as empresas definirem as normas da regulação do trabalho. Isso se sentiu na tendência a uma maior descentralização da negociação coletiva no âmbito das empresas e na diminuição do contingente de trabalhadores cobertos por acordos ou convenções coletivas, sobretudo aqueles empregados nas pequenas empresas, onde os sindicatos têm pouca penetração (KATZ e DARBISHIRE, 2000; MADRICK, 2012; PRIETO, 1999a). Nos parlamentos e governos, por sua vez, numa conjuntura bastante adversa aos trabalhadores, o lobbie empresarial ou corporativo se mostrou muito mais poderoso para pressionar pela flexibilização ou desregulamentação das instituições de proteção do trabalho e da seguridade social. O desemprego elevado - e ele é muito mais produto da quebra do compromisso político com o quase pleno emprego do que de uma inexorabilidade econômica (BOURDIEU, 1998) - também explica o fato de os sindicatos, em toda parte, terem tido de fazer concessões nas negociações coletivas (moderação ou redução de salários em troca de emprego, flexibilização das jornadas, troca de empregos fixos por temporários, expansão do emprego part-time) e terem perdido poder político no campo da definição das políticas macroeconômicas e sociais ${ }^{4}$.

\footnotetext{
${ }^{4}$ A literatura sobre o assunto já é vasta e cresce o número de estudos em perspectiva comparada. Ver, entre outros: Boyer, (1995); Köhler, (1999); Prieto, (1999a); Prieto, (1999b), Fudge e Vosko, (2001); Stanford e Vosko, (2004); Fantasia e Voss, (2004); Dombois, (1999); Druck (2007); Antunes, (2000); Costa (2007).
} 
A desregulamentação, a regulamentação da precariedade (FUDGE e VOSKO, 2001), a institucionalização da instabilidade (THÉBAUD-MONY e DRUCK, 2007) são expressões que tentam caracterizar essa tendência mais ampla de flexibilização negativa para os trabalhadores - das instituições do trabalho. Mais que isso, elas indicam que, ao lado da degradação das condições de emprego e salários, torna-se também precária a proteção social. Esta que foi justamente criada em torno do emprego, sustentada por ele, também entra em crise quando se agrava o desemprego ou são reduzidas ou extintas as cotizações sociais advindas dos empregos ditos precários, cada vez mais informais, que são os que mais crescem na nova economia. E o que eles têm em comum? Vínculos instáveis e inseguros (part-time, temporários, casuais, contingenciais), de baixa qualificação (mas nem sempre), de baixíssimos salários, de fraca organização sindical, predominantemente ocupados pelos trabalhadores imigrantes, pelas mulheres e pelos jovens.

A subcontratação, que caminha de mãos dadas com esse processo, é, pois, uma das formas de o capital flexibilizar o trabalho; uma flexibilidade que gera precariedade, incerteza, instabilidade e que não é periférica ou marginal, atinge mesmo o núcleo duro da sociedade salarial: o emprego estável, de longo prazo, protegido politicamente e cujo alcance social se encontra para além da esfera da produção e da distribuição da riqueza. As consequências da flexibilização do trabalho nesta nova dinâmica de acumulação do capitalismo são mais problemáticas justamente por seus efeitos destrutivos no campo de um ideal (e efetivo mecanismo) de socialização em que o trabalho (nos moldes do paradigma do emprego tradicional) aparece como principal elemento de coesão e integração social. O campo onde foram construídas as identidades coletivas que direcionaram o próprio conflito de classe e no qual os indivíduos encontram um sentido de pertencimento.

Esse é o ponto de chegada das reflexões de Castel (2005) sobre o desmonte da sociedade salarial. A instalação da precariedade nos países desenvolvidos aponta para uma tendência cada vez mais generalizada de desestruturação dos mercados de trabaIho, o que submete os trabalhadores a uma trajetória frontalmente oposta àquela da integração por meio da universalização de direitos: vulnerabilidade social, desemprego, desfiliação. São trajetórias erráticas feitas de alternância entre emprego precário e desemprego. Os trabalhadores, explorados por essa dinâmica de acumulação, têm a precariedade como destino; são interinos permanentes e têm, na constante expectativa de serem dispensados, a coerção disciplinadora. Eis aqui, ainda tendo Castel como referência, o elemento mais pernicioso: o crescente déficit de lugares ocupáveis na estrutura produtiva leva ao crescimento dos supranumerários, dos inúteis para o mundo; uma inutilidade que desqualifica os indivíduos, também, no plano cívico e político. São os não atores sociais, os não forças sociais, visto que "[...] falta-Ihes a base sobre a qual havia sido edificada sua identidade social"' (CASTEL, 2005, p. 531). Eis, então, o mundo da não política, o reino do mercado, onde prevalece a lei do mais forte.

O ponto chave dessa questão, e certamente Castel encontra subsídio analítico nas reflexões originais de Karl Polanyi (1980), é que o problema da integração e da coesão social não pode ser entregue exclusivamente à empresa, que atua pela lógica da competitividade e do mercado. Esse papel é essencialmente do Estado, o locus da política, a quem cabe minimamente primar pelo interesse coletivo e pela paz e bem-estar social. Nesse campo, todavia, uma vez retraída a participação política dos trabalhadores e uma vez retraídos os movimentos de esquerda no mundo, entra em xeque o poder do Estado para regulamentar a atividade produtiva e o seu papel social. As desregulamentações e as regulamentações que legitimam a instabilidade e a precariedade são um sinal de que o Estado se retira ou, melhor, de que ele passa a representar muito mais fortemente os interesses corporativos; um regime de regulação política que reforça as relações de dominação e controle sobre a força de trabalho e amplia a exploração (BOURDIEU, 1998).

E o que acontece nas regiões mais abaixo da linha do Equador, mais especificamente, no Brasil? Que espécie de regime de regulação fordista construímos no pós-guerra e em que sentido se dá o seu desmonte? É possível apropriar à realidade brasileira a noção de construção de uma sociedade salarial? Se sim, qual a sua característica e como ela se transforma com a nova dinâmica da acumulação flexível? Qual o papel da terceirização, jargão que a subcontratação assume no contexto brasileiro, nesse processo? É o que se passa brevemente a discutir.

\section{O PADRÃO DE ASSALARIAMENTO NO BRASIL}

É impossível entender o processo recente de ampliação dos regimes de emprego flexíveis, precários e, sobretudo, informais no Brasil sem pormenorizar, ainda que brevemente, a origem e as características da institucionalização do mercado de 
trabalho no país ${ }^{5}$. A lei nacional, a Consolidação das Leis do Trabalho (CLT), promulgada em 1943, definiu os direitos individuais básicos de proteção ao trabalhador e a estrutura da representação de classe, ainda hoje vigentes no país. Resultado das pressões do movimento trabalhista desde finais do século XIX, a CLT respondia à necessidade de incorporação política dos trabalhadores urbanos da indústria nascente. Os sindicatos foram reconhecidos, mas o Estado tomou para si o completo controle administrativo e político de suas atividades. A contrapartida veio pela imposição legal às empresas de reivindicações trabalhistas elementares, objeto de décadas de luta. A CLT consolidava um conjunto de leis arbitrando o uso do trabalho na indústria nascente e restringindo a liberdade de contratação das empresas: limitação da jornada de trabalho em 48 horas, proibição do trabalho de menores de 14 anos, regulamentação do trabalho feminino, remuneração obrigatória da hora extra, descanso de final de semana e férias remuneradas, condições de salubridade e proteção contra acidentes de trabalho, entre outros. A história é mais longa e conturbada, mas o que se quer destacar aqui é que, no Brasil, o Estado assumiu o papel central na regulação e mediação dos conflitos entre capital e trabalho e o fez pela via da cooptação e do apaziguamento entre as classes como forma de sustentar seu projeto nacionalista de industrialização. No âmbito dos direitos individuais, a CLT tinha, para a época, feição progressista. Todavia, no âmbito coletivo, o controle sobre os movimentos do trabalho foi peremptório e autoritário. A barganha coletiva não teve a importância política e econômica alcançada nos países democráticos. Não vingou entre nós a noção de conciliação e concertação política baseada na negociação autônoma de interesses entre grupos (capital e trabalho) organizados.

Ainda que o mercado de trabalho tenha sido regulamentado, suas instituições incorporaram os trabalhadores de forma limitada por duas frentes. Primeiro porque a legislação de direitos mínimos e de sindicalização deixava de fora a grande massa dos trabalhadores rurais; na época, absoluta maioria da força de trabalho no país. Até os anos 70, sob regime militar e para atenuar os conflitos no campo, os trabalhadores rurais ficaram submetidos às leis do mercado e da milícia dos seus patrões, sem a cobertura de direitos legais. Essa foi uma forma de Vargas compensar a perda do poder político-econômico das oligarquias agroexportadoras. Da mesma maneira, a legislação trabalhista não alcançava os servidores do serviço público, submetidos aos vieses da burocracia patrimonialista e clientelista do Estado. Um estatuto de direitos e deveres próprios a esta categoria só foi instituído em 1990, mas garantiu a soberania do Estado na definição dos termos do trabalho.

Uma segunda e significativa limitação da regulamentação do mercado de trabalho no país, que restringiu enormemente seu alcance, reside no fato de que grande parcela dos trabalhadores urbanos não gozou do status do emprego regulamentado e sobre o qual o Estado definia as políticas de seguridade social. Portanto também não vingou entre nós a noção de uma política macroeconômica pautada na geração de demanda agregada advinda dos esforços para garantir o pleno emprego e a universalização de direitos. Como o país viveu regimes políticos autoritários durante boa parte da história do seu desenvolvimento econômico e da construção das instituições do mercado de trabalho e da proteção social, não houve alternância de poder capaz de levar partidos que representassem os interesses das massas trabalhadoras às cúpulas de governo, onde são definidos os projetos de interesse coletivo.

De Vargas à queda do Regime Militar, o Brasil instaurava um projeto de industrialização de base técnica eminentemente fordista (forte hierarquia, extrema divisão do trabalho, controle autoritário sobre a força de trabalho), mas sem as concessões da política: portanto sem realizar distribuição de renda. As negociações coletivas foram praticamente figura morta até a redemocratização do país. Isso significou que, no período em que o país mais crescia, os salários estavam controlados por medidas de governos autoritários. Já o Estado social foi débil, fragmentado e excludente. Como argumentou Gomes (2006), as lutas de classe ou não foram suficientemente estruturadas ou foram prontamente reprimidas, de modo que as políticas de bem-estar, desarticuladas entre si e efêmeras, não sofreram a sua influência e responderam mais aos interesses de controle social das classes dominantes.

A intervenção no âmbito da política social do Estado brasileiro é outro ângulo por onde se podem apreender os determinantes da abismal desigualdade socioeconômica no país e o fechamento político às classes trabalhadoras dos espaços em que são definidos os interesses coletivos. Em todos os países desenvolvidos e, sobretudo, nas sociais-democracias europeias, a construção do sistema educacional e da saúde pública, por exemplo, se deu à base de muita luta do movimento trabalhista e social na defesa de que estes constituíssem direitos cidadãos, portanto, públicos e universais. No Brasil, a construção dessas esferas básicas da ação social do Estado se deu sob o domínio do interesse privado, mercantilizadas de uma maneira tal

${ }^{5}$ As reflexões deste e dos dois parágrafos abaixo são mais profundamente desenvolvidas em Costa (2005). 
que se constituíram sistemas duais, elitizados: a saúde dos que podem pagar e a saúde dos pobres, a escola paga dos ricos e das classes médias e a escola pública para os pobres, restringindo o acesso das massas a esses direitos e truncando, desde a origem (de classe, de cor), as possibilidades de mobilidade social.

Com sindicatos controlados, partidos de esquerda banidos e a maioria dos trabalhadores sem auferir direitos, o crescimento econômico realizou-se sem uma associação direta com o aumento do padrão de renda/consumo e bem-estar da população e sem qualquer compromisso mais sólido com uma política de pleno emprego (pautada na estabilidade). Ao contrário, como originalmente argumentou Francisco de Oliveira (2005), certo desemprego estrutural foi benéfico ao tipo de acumulação escolhido e funcional à geração de um mercado de trabalho de oferta abundante, de baixíssima remuneração, espaço de proliferação das inúmeras formas de trabalho subterrâneo, informal e precário. Em outras palavras, a massa trabalhadora não participou do processo de crescimento e de acumulação capitalista da sociedade brasileira, de maneira que não houve efetiva redistribuição dos ganhos de produtividade da economia. Adicione-se a isso a inexistência de um sistema amplo de regulação coletiva que tivesse por base a garantia de direitos cidadãos e se tem um quadro de forte heterogeneidade estrutural das condições de trabalho e emprego, restringindo o poder de abrangência da legislação trabalhista e da seguridade social. Essa realidade é profundamente agravada nos anos de 1990, com o emprego informal superando as estatísticas do emprego formal.

Se a expansão e a modernização industrial brasileira do pós-1930, sobretudo a dos anos 50 e 60, com a vinda das multinacionais, permitiram alguma mobilidade social, permitiram também, e contraditoriamente, uma enorme diferenciação das ocupações e dos salários, impedindo que se reduzisse a desigualdade de classe no país. Empregos e salários tornaram-se variáveis extremamente flexíveis de ajuste econômico, excluindo parcela considerável da população dos benefícios do crescimento e ampliando os bolsões de pobreza. A informalidade do mercado de trabalho, por sua vez, teve historicamente papel relevante e facilitador dessa flexibilidade. É nesse sentido que, comparativamente à realidade muito mais abrangente e homogênea da institucionalização do mercado de trabalho e das políticas de bem-estar dos países desenvolvidos, o Brasil jamais conseguiu criar uma classe média ampla, afluente, com poder de consumo (HASEMBALG e SILVA, 2003; MATTOSO, 1996; OLIVEIRA, 2003).

Há que, certamente, se ressaltar a revitalização do movimento sindical de final dos anos de 1970, e por toda a década seguinte, e sua importância política. O chamado novo sindicalismo surgiu enraizado nas bases, pelo confronto direto com os patrões e o Estado, reivindicando a negociação coletiva, a representação nos locais de trabalho, o direito de greve, ao mesmo tempo que encabeçava os movimentos sociais pela redemocratização do país. Inaugurando um estilo de ação sindical combativo e apoiado pela militância e mobilização ativa dos trabalhadores, os sindicatos passaram a pressionar os patrões pela abertura de canais de negociação direta, deslocando a resolução dos conflitos, antes concentrados na Justiça do Trabalho, para o interior das empresas e para o âmbito dos acordos coletivos.

No entanto, ainda que este tenha se constituído de um momento de ascensão de forças sociais antes rechaçadas do cenário político - e cabe destacar aqui a constituição das duas atuais grandes centrais sindicais (CUT e CGT, hoje Força Sindical) e do Partido dos Trabalhadores - e ainda que tenham sido conquistados dispositivos democráticos importantes na Constituição de 1988, pouco se avançou em termos de uma efetiva e democrática mudança institucional no regime de relações de trabaIho e na estrutura fundiária do país. As centrais sindicais e os movimentos populares encontraram enormes dificuldades para articular formas mais amplas de representação política, capazes de influir significativamente nas decisões governamentais relativas a política econômica e social, sobretudo no âmbito das políticas redistributivas (MEDEIROS, 1994; OLIVEIRA, 1994). Ao contrário, os ventos neoliberais soprados fortemente no país no início da década de 1990 (a abertura econômica e as privatizações) e a reestruturação produtiva nas empresas arrefeceram o impulso de luta dos sindicatos.

Fechamento de plantas e enxugamento de quadros, num contexto de baixíssimo crescimento, tiveram como principal consequência um fenômeno de demissão em massa jamais vivido na história da industrialização do país. No campo das decisões estratégicas no nível organizacional, sobressaiu-se, muito mais do que as inovações tecnológicas, a introdução dos novos métodos de organização e gestão do trabalho, de inspiração toyotista, pautados muito fortemente na desverticalização e na conquista subjetiva dos que ficaram. É desse contexto que se expandem e emergem novas cadeias e formas diversas de subcontratação. A terceirização nas grandes empresas, organizada com base numa profusão de pequenas firmas, muitas delas funcionando em uma relação de exclusiva dependência de suas contratantes, constituiu-se numa das estratégias centrais de ajuste competitivo, focada, sobretudo, na redução dos custos do trabalho. De uma perspectiva agregada, como será discutido logo mais, ela significou a substituição de empregos regulares e com certo padrão de conquistas por empregos precários, temporários, muitas vezes não regulamentados (MATTOSO, 1996; POCHMANN, 2002). 
No campo legal, avançaram as medidas de flexibilização da legislação trabalhista. Em 1997 e 1998, como reflexo das iniciativas liberais apoiadas no discurso de que o desemprego era fruto da rigidez da legislação, um pacote de medidas, arbitradas pelo governo federal, legalizou: o banco de horas, que substituía o pagamento das horas-extras; a suspensão temporária do contrato de trabalho por motivos econômicos; o contrato de trabalho por tempo determinado, com redução dos encargos sociais; a redução do salário com redução da jornada; as cooperativas de trabalho, que estimularam, como produto da subcontratação, o crescimento do trabalho autônomo, desprovido da proteção dos direitos do emprego regular; a abertura do comércio varejista aos domingos sem o pagamento de horas extras e sem obrigação de negociação com os sindicatos; entre outros. Essas medidas de modificação da legislação trabalhista se mostraram extremamente perniciosas aos trabalhadores porque implicavam redução ou retirada dos já parcos direitos ali estabelecidos e foram incapazes de gerar novos empregos ou ampliar a formalização dos já existentes ${ }^{6}$.

Resultado das mudanças na economia e no mercado de trabalho brasileiro é que elas agravaram o processo de desestruturação do mercado de trabalho no país, ampliando a informalidade. O movimento de consolidação da economia organizada e do trabalho formal, que no auge do período de crescimento econômico, a década de 70 , atingiu apenas $50 \%$ da população economicamente ativa empregada no meio urbano (POCHMANN, 2002), sofreu significativa inflexão na década de 1980, asseverando as desigualdades estruturais, e experimentou mesmo a sua reversão a partir da década de 1990 como decorrência dos ajustes econômicos pró-mercado. Isso pode ser observado na queda do nível de assalariamento formal: ainda segundo Pochmann (2002), 57\% das ocupações abertas entre 1980 e 2000 não tinham carteira de trabalho assinada. No mesmo período, a taxa de precarização do mercado de trabalho, considerada como a soma das ocupações por conta própria, dos sem remuneração e do total dos desempregados, cresceu de 34,1\% para 40,4\% da População Economicamente Ativa (PEA). Os dados da Pesquisa Nacional por Amostra de Domicílios (PNAD/2006) corroboram essas estatísticas. Naquele ano, os trabalhadores informais representavam $55 \%$ dos ocupados no país, dentre eles se destacavam os empregados sem carteira, 32\%, e os trabalhadores por conta própria, 38\% (COSTA, 2010). A terceirização, que se discutirá logo a seguir, teve importância decisiva nesse processo de desestruturação e ainda maior precarização do mercado de trabalho brasileiro.

\section{SUBCONTRATAÇÃO NO BRASIL: TRABALHO AINDA MAIS FLEXÍVEL E A REITERAÇÃO DE UM PADRÃO PREDATÓRIO DE ACUMULAÇÃo}

A subcontratação ou terceirização, como é mais conhecida, não é algo novo no Brasil. Subcontratar de terceiros era, até o final da década de 1980, uma prática ainda muito restrita às necessidades das empresas de substituir trabalhadores (em período de férias, por exemplo) ou cobrir demandas sazonais, e à atividade de segurança patrimonial. A terceirização discutida aqui, e a expressão mesma é um neologismo, é produto das formas contemporâneas de organização do processo de trabalho, produto da empresa enxuta, desverticalizada. O novo é a amplitude das atividades que ela passa a abranger, ou seja, a dimensão que alcança na economia: de atividades meio ou extremamente periféricas como conservação, limpeza, segurança patrimonial, alimentação, a atividades centrais do processo produtivo, subcontratadas por uma gama cada vez maior de empresas.

O novo, também, é que a terceirização passa a ser sinônimo de rebaixamento generalizado das condições de trabalho e salário de inúmeras categorias de trabalhadores que antes gozavam do status de serem efetivas das contratantes, normalmente grandes empresas onde as relações de trabalho são mais protegidas pela negociação coletiva e pela legislação. A terceirização, no caso brasileiro, mais que uma estratégia de especialização, constituiu-se no principal mecanismo de redução dos custos do trabalho por permitir que as empresas transferissem para terceiros as responsabilidades legais da contratação. Sua propagação nos anos 1990 se beneficiou tremendamente do contexto político que propugnava maior liberdade para as empresas demitirem e contratarem, legitimando a adoção dos contratos flexíveis de trabalho, regulamentados ou não.

As medidas neoliberais de flexibilização do mercado de trabalho de meados dos anos 90 contribuíram para expansão da terceirização por meio de modalidades outras que a do típico contrato temporário, do trabalho autônomo ou das redes de empresas fornecedoras de produtos ou prestadoras de serviços, já regulamentados. A terceirização se expandiu, sobretudo,

\footnotetext{
${ }^{6}$ Para uma análise contundente das transformações na economia e no sistema de relações de trabalho brasileiro na década de 1990 ver, entre outros, Boito Jr. (1999); Cardoso (2003); Krein (1999).
} 
pela via do trabalho sem registro em carteira e do trabalho clandestino, pela via da pura intermediação de mão de obra, e também pela via de uma modalidade nova, legalizada, ainda que descaracterizando a sua natureza, que foi a da constituição das cooperativas de trabalho (THÉBAUD-MONY e DRUCK, 2007).

A lei que regulamenta as cooperativas de trabalho, de 1994, instituiu que não existe vínculo empregatício entre a cooperativa, qualquer que seja a sua atividade, e os seus cooperados, e nem entre estes e os tomadores de serviço. Esse instituto permitiu que várias empresas desmontassem estruturas e demitissem trabalhadores para recontratá-los por meio de cooperativas, mantendo as mesmas relações de subordinação, sem, contudo, auferirem os direitos de um trabalhador assalariado. Caracterizadas pela extrema relação de dependência e subordinadas à hierarquia, à organização do processo de trabalho e às demandas de suas contratantes, as cooperativas de trabalho funcionam como intermediadoras de mão de obra, constituindo-se num mecanismo legal de exploração e precarização do trabalho.

Não há estatística agregada sobre a terceirização no Brasil e isso muito fortemente se explica devido à crescente complexidade da configuração das cadeias produtivas e à diversificação das estratégias de negócios. Estudos específicos como os realizados pelo Departamento Intersindical de Estatística e Estudos Socioeconômicos (DIEESE) apontam que o tempo de emprego em setores tipicamente terceirizados corresponde à metade dos setores tipicamente contratantes. A remuneração é em média $27 \%$ inferior e a taxa de rotatividade anual chega a 45\%, enquanto nos contratantes é de 22\% (MANZANO, SANTOS e TEIXEIRA, 2013). Outro dado alarmante do fenômeno são os elevados casos de empresas terceiras que desaparecem sem cumprir suas obrigações trabalhistas.

É relativamente considerável, no entanto, a produção empírica, especialmente no campo da sociologia e da economia do trabalho, focada em setores ou segmentos nos quais a terceirização de atividades consideradas como sendo nucleares vem avançando significativamente. Estudos específicos em segmentos da indústria como a petroquímica (DRUCK, 1999; DRUCK e BORGES, 2002), a metal-mecânica (MARCELINO, 2002), a de confecções (AMORIM, 2003; LIMA, 2004; 2002; MARTINS e RAMALHO, 1994) e a de calçados (NAVARRO, 2006); e do setor de serviços como bancos (JINKINGS, 2006; SILVA, 2006), telecomunicações (LARANJEIRA, 2003) e serviços públicos (BORGES, 2004) têm em comum o argumento de que a terceirização no país implicou um amplo processo de precarização do trabalho. Druck e Borges (2002) falam de um processo de "quádrupla precarização", às quais agregam-se a seguir as reflexões consideradas aqui pertinentes.

1. Precarização dos regimes de emprego - de forma legal ou mais acentuadamente por intermédio da informalização da economia, permite que as empresas adotem estratégias de flexibilidade e ajuste às demandas do mercado pela via da redução dos encargos trabalhistas e dos salários. Neste aspecto, cabe ressaltar que, mais que medidas emergenciais para escapar às agruras da crise, a flexibilização dos contratos de trabalho (temporário, de estágio, autônomo, cooperado, informal) se impõe no nosso país reiterando um padrão predatório de regulação e de desenvolvimento capitalista. A retração dos já parcos direitos do trabalho a que essa flexibilização leva é produto de pressão empresarial não apenas para que os governos adotem políticas neoliberais de desregulamentação dos mercados de trabalho ou de sua regulamentação em patamar inferior de direitos, mas também é produto de pressão por um maior afrouxamento de seus controles e de sua função fiscalizadora. É nesse sentido que boa parcela do crescimento da informalidade do trabalho dos anos 90 no país pode ser explicada pela redução e evasão, por parte das empresas, do cumprimento dos encargos trabalhistas e sociais, e isso em muito se deve aos baixos custos da ilegalidade ${ }^{7}$. Em outras palavras, o que aqui se afirma é que as recentes estratégias de acumulação do capital se beneficiam, também, da tolerância e da falta de controle do Estado para expandir e recriar diversas modalidades de atividade produtiva e de exploração do trabalho, reiterando uma tendência secular de burla ao ordenamento jurídico, prejudicial não apenas aos trabalhadores, mas a todo o conjunto da sociedade uma vez que o Estado tem não apenas a sua base tributária reduzida, mas também a sua própria capacidade de regulamentar a economia (DIEESE, 1999a; PORTES e CASTELLS, 1989; SILVA, 2003).

2. Precarização das condições de trabalho e salário - a redução dos custos do trabalho aparece na literatura como uma das razões centrais para as empresas optarem por subcontratar determinados serviços ou etapas do processo produtivo. Isso se torna possível porque as subcontratadas são empresas menores que se utilizam mais prontamente dos contratos flexíveis de trabalho, tipicamente mais precários em termos de direitos e salários, e por serem mais instáveis. A imagem é aquela da passagem do emprego na grande empresa fordista - mais estruturada e cujos trabalhadores são de alguma forma protegidos pelas conquistas da negociação coletiva - para o emprego

\footnotetext{
7 Por esse critério, no cálculo racional dos empresários vale a pena sonegar e ludibriar porque os custos de uma eventual descoberta e punição são compensados pelos ganhos decorrentes da sonegação.
} 
fragmentado em pequenas e microempresas, sem os direitos antes garantidos na grande empresa. Nas terceiras os salários são menores, inexistem ou são inferiores alguns benefícios como alimentação e transporte, há extrema dificuldade de organização sindical, faltam políticas de treinamento e qualificação, são precárias as condições de salubridade e segurança (DIEESE, 1994). Ademais, a pressão por produtividade e por dar conta das demandas da contratante em tempo curto intensifica o ritmo de trabalho dos terceiros. Isso foi evidente nos processos de terceirização das antigas estatais privatizadas, no serviço público, nos bancos, na indústria petroquímica, metalmecânica, de confecções e calçadista. Ademais, "[...] os terceirizados realizam uma jornada semanal de, em média, três horas a mais do que a dos empregados diretos. Se a jornada deles fosse igual a dos contratados diretamente, seriam criados 801.383 empregos" ${ }^{\prime 2}$.

3. Mas a precarização das condições de trabalho e salário atinge também os empregados da contratante. Atinge mesmo, de uma forma agregada, a qualidade dos postos de trabalho formais (DRUCK e BORGES, 2002), uma vez que a terceirização implica redução do quadro das grandes empresas. Ela intensifica, também ali, as pressões por produtividade na base da insegurança e do medo da perda do emprego (além das incertezas econômicas, há sempre a possibilidade de um novo setor ou atividade serem terceirizados). Mais que isso, a terceirização enfraquece a ação coletiva e a capacidade de o sindicato barganhar melhores condições de trabalho e salário.

4. Precarização da saúde - consequência das outras formas de precarização, da insegurança vivida em relação ao emprego, da intensificação dos ritmos de trabalho, da extensão das jornadas, do descaso ou dos baixos investimentos na qualificação do trabalhador, nos ambientes de trabalho e nas políticas de segurança. Deteriora-se, também, a saúde dos trabalhadores. A própria expansão da terceirização nas empresas privadas para as áreas responsáveis pela segurança e medicina do trabalho, que se tornam, como disseram Thébaud-Mony e Druck (2007), um "serviço periférico", é um indicativo do grau de negligência para com um dos problemas centrais das relações de trabalho no país: o elevado índice de acidentes de trabalho e de doenças profissionais, sobre os quais os trabalhadores (seus sindicatos) e os órgãos públicos passam a ter cada vez menos controle.

5. Precarização da ação coletiva-essa, certamente, a consequência mais deletéria da terceirização para os trabalhadores porque gera fragmentação e fragiliza a ação política dos sindicatos em sua capacidade mesma de limitar ou reverter a tendência de expansão da terceirização e flexibilização do trabalho, seja no âmbito das negociações coletivas seja no âmbito da política mais ampla. Os trabalhadores são divididos - mesmo no interior de uma mesma empresa -, e com emprego mais instável e de elevada rotatividade é muito mais difícil criar identidades, organizar e mobilizar os trabalhadores terceirizados, representados (quando formais) por sindicatos menores e mais fracos que, também, muito dificilmente conseguem se articular com o sindicato das empresas contratantes.

Criam-se, assim, as distinções e as discriminações: os terceiros fazem as tarefas menos nobres e, muitas vezes, trata-se das mesmas tarefas de um trabalhador da empresa contratante, mas sempre com um status diferenciado, inferior. Nas pesquisas empíricas já referenciadas acima são comuns os relatos de trabalhadores que, realizando seu trabalho nas instalações da contratante, se sentem discriminados, humilhados, subordinados aos mandos dos empregados daquela, invisíveis num ambiente em que prevalece outra cultura e identidade de classe. A divisão gera, por sua vez, competição, tanto no plano individual (os terceiros guardam o sonho de serem efetivados e os efetivos trazem sempre o receio de se tornarem terceiros ou desempregados), como no plano coletivo, sobretudo pela tendência a ações corporativistas por parte de sindicatos arraigados às formas tradicionais de representação. A ideia aqui é que, diferentemente do capital que é capaz de integrar uma produção desconcentrada e fragmentada globalmente, o sindicalismo tradicional não foi capaz de acompanhar as mudanças na estrutura produtiva e articular estratégias de representação mais abrangentes, ampliando seu escopo político de ação para incluir a representação de trabalhadores desempregados, precarizados ou excluídos do núcleo central da produção.

\section{À GUISA DE CONCLUSÃO}

As formas contemporâneas de subcontratação estão no centro de um processo mais amplo de flexibilização das instituições sociais e do trabalho. Elas trazem consigo as marcas da vulnerabilidade, da insegurança, da pobreza, da regulamentação do trabalho em patamares inferiores de direitos e, sobretudo, da negação política. Esse, talvez, o aspecto mais nefando, visto que limita ou mesmo coíbe a organização coletiva dos oprimidos. Mas esse processo mais amplo de flexibilização das instituições

\footnotetext{
${ }^{8}$ Fala do presidente da Central Única dos Trabalhadores (CUT), Artur Henrique, em audiência pública do Tribunal Superior do Trabalho (TST) em outubro de 2011 disponível em: http://www.seebt.com.br/index.php/imprensa/noticias/1658-cut-e-dieese-revelam-dados-nefastos-da-terceirizacao-em-audiencia-no-tst.
} 
sociais e do trabalho não pode ser entendido, conforme defendeu Bourdieu (1998), como uma fatalidade econômica. Ele é produto de decisões políticas que correspondem à vontade e a interesses de grupos que detêm o domínio econômico; é, portanto, produto de um maior unilateralismo patronal. O retraimento do movimento sindical e, muitas vezes, sua capitulação ao discurso neoliberal - os sindicatos aderiram, de forma geral, ao discurso do sacrifício em nome da competitividade representam mesmo um afastamento ideológico, e da ação coletiva, do campo do conflito aberto de classe e das velhas lutas por transformação social. Lutas essas protagonizadas pelos movimentos de esquerda e que pressionaram a abertura política responsável pelas conquistas atinentes a uma maior justiça social nas democracias contemporâneas (DAHRENDORF, 1992). Em todos os países industrializados os trabalhadores amargaram as perdas desse processo.

É preciso lembrar que o regime de regulação fordista, ao menos onde ele vingou de forma mais democrática e a despeito de todas as críticas que sofreu, foi produto de um pacto social, de políticas de reciprocidade, ainda que sob a hegemonia do capital. Ele foi centralmente um pacto de âmbito nacional, por meio do qual os Estados nacionais detinham maior capacidade política de regulamentar a ordem social e econômica internamente. Os fenômenos do neoliberalismo e da globalização, que quebram as fronteiras da economia e das regulamentações, impõem severos desafios a esta capacidade regulatória, sobretudo no campo do mercado de trabalho, mais fragmentado globalmente. O grande desafio é conciliar, não mais em escala nacional, mas em escala global, as demandas de competitividade e de flexibilidade das empresas com um padrão minimamente homogêneo de regulação social e de emprego, no que possa se constituir uma ordem mais includente, que envolva a garantia de emprego e de direitos, contrária à tendência precarizante da qual a terceirização é emblemática. Isto estaria a exigir uma nova hegemonia do capital, mediada não mais exclusivamente no âmbito nacional, mas no supranacional, e que seja produto da pressão e da articulação coletiva dos trabalhadores (dos seus sindicatos) e dos movimentos sociais em nível internacional. A lógica neoliberal ainda predominante, que torna os Estados reféns da liquidez imediata do Capital, e a fragmentação do movimento coletivo do trabalho impedem ou limitam, no entanto, essa articulação (DINIZ, 2007; SANTANA e RAMALHO, 2003). Com o desmonte da sociedade salarial e à medida que se asseveram as relações de dominação, voltam à tona os problemas que questionam os próprios fundamentos do modo de produção e valorização capitalista e para os quais as sociedades industrializadas estão longe de construir um novo consenso.

As implicações econômicas e sociais desse processo parecem explodir com mais veemência na atual conjuntura de crise, ponto culminante de uma situação que vem se agravando desde os anos de 1980. A destruição dos milhares de postos de trabaIho que a economia mundial registrou depois da crise financeira de 2008-2009 e a espiral recessiva registrada desde então são produto dos castelos de areia da mais pura especulação financeira e de uma crise de superprodução que se poderia com uma questão problematizar: como trabalhadores desempregados ou rebaixados em sua condição salarial podem dar conta, como consumidores, do boom produtivista da era da acumulação flexível? É essa dinâmica que traz à tona as reflexões sobre a nova questão social, de que falava Castel (2005) e à qual se pode agregar a não tão nova questão ambiental, ambas pondo em xeque as ilusões do progresso e a ordem mesmo do sistema de acumulação. Sua face mais cruel pode ser visualizada no crescimento da pobreza (concentração de renda), da intolerância e da violência no mundo (WACQUANT, 2001).

No caso do Brasil - onde as questões da pobreza e da desigualdade acompanharam desde sempre seu projeto de modernidade e industrialização -, do comportamento da economia e do mercado de trabalho na década de 1990 sobressaiu uma tendência bem contrária àquela que postulava a expansão dos empregos: o movimento de terciarização da economia que acompanhou a expansão da subcontratação no país não foi capaz de absorver os empregos destruídos pela reestruturação produtiva sistêmica do setor secundário. Mais que isso, esse movimento foi responsável pela transformação de empregos regulares em desemprego e em subemprego, seja pela informalização da economia, seja pelas medidas legais (arbitrárias) apontadas como inexoráveis e imprescindíveis ao ajuste competitivo do país e que legitimaram uma maior flexibilização dos vínculos de emprego e das condições de trabalho. Essas mudanças contribuíram para fragilizar ainda mais a estrutura do mercado de trabalho no país, historicamente marcada pelos baixos salários, pela excessiva instabilidade do vínculo empregatício, pela baixa qualificação dos seus trabalhadores, pela fraca organização coletiva, pelos parcos direitos cidadãos.

As mudanças trazidas pelos três governos do Partido dos Trabalhadores no pós-2003 apontaram para certa reversão na desestruturação do mercado de trabalho registrada nos anos 1990, marcados por políticas pró-mercado. 0 aumento do emprego formal (que registrou um crescimento médio anual de 6,0\% entre 2003-2012), diminuindo a participação relativa dos trabaIhadores sem carteira e dos autônomos, e a política de valorização do salário mínimo (que registrou um ganho real médio de $5,5 \%$ ao ano no mesmo período), concomitante à conquista em negociação coletiva de ganhos reais no salário de diversas 
categorias de trabalhadores, contribuíram para uma melhor estruturação do trabalho assalariado e para redução da desigualdade de renda no país (MANZANO SANTOS e TEIXEIRA, 2013). No entanto, reconhecem esses mesmos autores, a despeito dos inequívocos avanços no campo do emprego e da renda, as transformações recentes na organização da produção, no seio das quais a terceirização aparece como estratégia central amplamente utilizada pelos mais diversos setores, vêm impondo intensos e complexos desafios à capacidade de regulação pública do trabalho. É nesse sentido que, à medida que a terceirização avançou na primeira década do século XXI sob a égide de governos que, embora tenham mantido, na essência, os rigores da política neoliberal, são mais afeitos aos interesses dos trabalhadores e retomam o protagonismo do Estado na condução da economia e das políticas sociais, também se registrou uma crescente mobilização política em torno de um marco regulatório específico para o tema.

O embate político-jurídico envolve a difícil conciliação de interesses entre parlamentares, centrais sindicais, Ministério do Trabalho, Ministério Público do Trabalho, Fórum Nacional Permanente em Defesa dos Trabalhadores Ameaçados pela Terceirização e entidades empresariais em torno de um projeto de lei que regulamente a terceirização. O projeto de lei mais cotado, o 4330/2004, já aprovado na Câmara dos Deputados, ao qual foram apresentadas inúmeras emendas e, até mesmo, um projeto de lei substitutivo, enfrenta forte resistência dos representantes da classe trabalhadora e, também, de vários membros das instâncias jurídicas do país (Ministério Público do Trabalho, Tribunal Superior do Trabalho), por se tratar de proposta marcadamente pró-empresários. Ele defende a possibilidade de ampliação da terceirização para as atividades-fins e limita ou elimina a solidariedade da empresa contratante em caso de inadimplência das obrigações trabalhistas da terceira, duas dentre as questões mais problemáticas que impedem o consenso (BIAVASCHI, 2013). No momento em que se fecha esta redação, o país atravessa nova crise política e econômica, com queda nos indicadores de emprego e da renda. Nesse contexto, a aprovação de um projeto de lei que fortalece a classe empresarial e de medidas provisórias que mexem com direitos do trabalhador, a exemplo das mudanças nas regras do seguro-desemprego, apontam para a temeridade de uma ampliação ainda maior das formas precárias de emprego no país.

No entanto, a despeito dos avanços no mercado de trabalho, é ainda bastante elevada a informalidade e muitos dos empregos criados na última década respondem a regimes de trabalho que, embora formais, fazem uso amplo e diverso do trabalho temporário, inseguro, de baixos salários. Embora o espaço político seja mais aberto, a exemplo dos diversos fóruns constituídos nos governos Lula, com participação das entidades que representam os trabalhadores e diversos segmentos sociais para discussão das políticas sociais e do emprego, pouco se avançou na proposição de uma reforma efetivamente democrática na legislação trabalhista e, contrariamente, houve até mesmo avanço de medidas pontuais no sentido de permitir mais flexibilização do trabalho (ver KREIN, SANTOS e NUNES, 2012). Ainda que a economia cresça e que haja uma ampliação do emprego regulado, como vem sendo registrado nos últimos anos, embora com notável instabilidade, sem reformas estruturais profundas e democráticas no sistema de relações de trabalho e na estrutura fundiária, muito dificilmente o Brasil reduzirá seu vergonhoso quadro de desigualdades econômicas e sociais. 


\section{REFERÊNCIAS}

AMATO, F. Presidente do TST diz que lei sobre terceirização é urgente. G1.globo.com, 4 out. 2011. Disponível em:<http:// g1.globo.com/concursoseemprego/noticia/2011/10/

presidentedotstdizqueleisobreterceirizacaoeurgente.html>. Acesso em: 12 jun. 2015.

AMORIM, E. R. A. No limite da precarização: terceirização e trabaIho feminino na indústria de confecção. Dissertação (Mestrado) Departamento de Sociologia, UNICAMP, 2003. Mimeo.

ANTUNES, R. Os sentidos do trabalho: ensaio sobre a afirmação e a negação do trabalho. São Paulo: Boitempo, 2000.

BIAVASCHI, M. B. O capitalismo contemporâneo e as novas formas de contratação da força de trabalho: a terceirização. In: KREIN, J. D. et al. (Org.). Regulação do trabalho e instituições públicas. São Paulo: Fundação Perseu Abramo, 2013. 141-166 p.

BOITO JR., A. Política neoliberal e sindicalismo no Brasil. São Paulo: Xamã, 1999.

BOLTANSKI, L.; CHIAPELLO, E. O novo espírito do capitalismo. São Paulo: Martins Fontes, 2009.

BORGES, Â. M. Reforma do estado, emprego público e a precarização do mercado de trabalho. Caderno CRH, n. 41, p. 255-268, 2004.

BOURDIEU, P. Contrafogos. Rio de Janeiro: Ed. Jorge Zahar, 1998.

BOYER, R. Capital-labour relations in OCDE countries: from the fordist golden age to contrasted nacional trajectories. In: CAPITAL, THE STATE AND LABOUR: A GLOBAL PERSPECTIVE. London: United Nations University Press, 1995. 18-65 p.

CARDOSO, A. M. A década neoliberal e a crise dos sindicatos no Brasil. São Paulo: Boitempo, 2003.

CASTEL, R. As metamorfoses da questão social. 5. ed. Rio de Janeiro: Vozes, 2005.

CASTELLS, M. A sociedade em rede. São Paulo: Paz e Terra, 2001.

CHESNAIS, F. A mundialização do capital. São Paulo: Xamã, 1996.

COSTA, M. S. O sistema de relações de trabalho no Brasil. Alguns traços históricos e sua precarização atual. Revista Brasileira de Ciências Sociais, v. 20, n. 59, p. 111-132, 2005.

COSTA, M. S. Relações de Trabalho e Regimes de Emprego no Canadá e no Brasil: um Estudo Comparativo. RAE - Eletrônica, v. 6, n. 2, p. 16-29, jul./set. 2007.

COSTA, M. S. Trabalho informal: um problema estrutural básico no entendimento das desigualdades na sociedade brasileira. Caderno CRH, v. 23, n. 58, p. 171-190, 2010.

DAHRENDORF, R. O conflito social moderno: um ensaio sobre a política da liberdade. São Paulo: Editora da Universidade de São Paulo, 1992.

DIEESE. Departamento Intersindical de Estatística e Estudos Socioeconômicos. Terceirização e Reestruturação produtiva do setor bancário no Brasil. São Paulo: Departamento Intersindical de Estatística e Estudos Socioeconômicos, 1994.
DIEESE. Pesquisa DIEESE. O comportamento das negociações coletivas de trabalho nos anos 90 - 1993-1996, n. 15, maio, 1999a.

DIEESE. Balanço das negociações salariais em 1998. Boletim DIEESE - Estudos e Pesquisa, jan., 1999b.

DINIZ, E. "O pós-consenso de Washington: globalização, estado e governabilidade reexaminados. In: DINIZ, E. (Org.). Globalização, estado e desenvolvimento. Rio de Janeiro: Ed. FGV, 2007. 16-62 p.

DOMBOIS, R. La erosión de las relaciones laborales en Alemania y las nuevas estrategias del empleo. In: PRIETO, C. (Dir.). La crisis del empleo en Europa. Alzira: Germânia, 1999. v. 1. 64-138 p.

DRUCK, G.; BORGES, A. Terceirização: balanço de uma década. Caderno CRH, v. 15, n. 37, p. 111-139, jul./dez. 2002.

DRUCK, M. G. Terceirização: Desfordizando a Fábrica - um estudo do Complexo Petroquímico. São Paulo: Edufba/Boitempo. 1999.

DRUCK, M. G. A flexibilização e a precarização do trabalho na França e no Brasil: alguns elementos de comparação. In: ENCONTRO ANUAL DA ANPOCS, 31. Caxambu, 2007. Disponível em: <http://portal. anpocs.org/portal/index.php?option=com_docman\&task=doc_vie$w \&$ gid $=3165$ \& Itemid=231 $>$. Acesso em: 29 fev. 2016.

ESPING-ANDERSEN. The three worlds of welfare capitalism. Cambridge, UK: Polity Press, 1990.

FANTASIA, R.; VOSS, K. Hard Work: Remaking the American Labor Movement. Berkeley, CA: University of California Press, 2004.

FUDGE, J.; VOSKO, L. By Whose Standard? Reregulating the Canadian Labour Market. Economic and Industrial Democracy, v. 22, p. 327 356, 2001.

GIOSA, L. A. Terceirização: uma abordagem estratégica. São Paulo: Pioneira, 1997.

GOLDTHORPE, H. et al. The affluent worker: Industrial atitudes and behavior. Cambridge University, 1968.

GOMES, F. G.. Conflito social e welfare state: Estado e desenvolvimento social no Brasil. Rev. Adm. Pública, v. 40, n. 2, p. 201-36, mar./abr. 2006

HARVEY, D. Condição pós-moderna. São Paulo: Edições Loylola, 1989.

HASEMBALG, C.; SILVA, N. V. Origens e destinos: desigualdades sociais ao longo da vida. Rio de Janeiro: Topbooks, 2003.

JINKINGS, N. A reestruturação do trabalho nos bancos. In: ANTUNES, R. (Org.). Riqueza e Miséria do trabalho no Brasil. São Paulo: Boitempo, 2006. 189-206 p.

KATZ, H.; DARBISHIRE, O. Converging Divergences. Itahaca, N.Y: ILR/ Cornell University Press, 2000.

KÖHLER, H. Las relaciones laborales españolas en el marco Europeo. In: MIGUÉLEZ, F.; PRIETO, C. (Dir.). Las relaciones de empleo en España. Madrid: Siglo XXI, 1999. 399-432 p.

KREIN, J. D. Reforma no sistema de relações de trabalho no Brasil. In: DIEESE (Org.) Emprego e desenvolvimento tecnológico. São Paulo: Dieese/Cesit/Unicamp, 1999. 
KREIN, J. D.; SANTOS, A. L.; NUNES, B. T. Trabalho no governo Lula: avanços e contradições. Texto para Discussão, Instituto de Economia, Unicamp, n. 201, fev. 2012.

LARANJEIRA, S. G. A reestruturação das telecomunicações e os sindicatos. Revista Brasileira de Ciências Sociais, v. 18, n. 52, p. 81-106, 2003.

LIMA, J. C. As artimanhas da flexibilização: trabalho terceirizado em cooperativas de produção. São Paulo: Terceira Imagem, 2002.

LIMA, J. C. Trabalho auto-gestionário em cooperativas de produção: o paradigma revisitado. Revista Brasileira de Ciências Sociais, v. 19, n. 56, p. 45-62, 2004.

MADRICK, J. The deliberate low-wage, high-insecurity economic model. Work and Occupations. SAGE Publications, 2012. 321-330 p.

MANZANO, M.; SANTOS, A. L.; TEIXEIRA, M. Desenvolvimento econômico e trabalho nos anos recentes. In: KREIN, J. D. et al. (Org.). Regulação do trabalho e instituições públicas. Fundação Perseu Abramo, 2013. v. 1.

MARCELINO, P. R. A logística da precarização: terceirização do trabalho na Honda do Brasil. Dissertação (Mestrado) - Departamento de Sociologia, UNICAMP, 2002. Mimeo.

MARTINS, H.; RAMALHO, J. R. Terceirização: diversidade e negociação no mundo do trabalho. São Paulo: Hucitec, 1994.

MATTOSO, J. A desordem do trabalho. São Paulo: Scritta, 1996.

MEDEIROS, C. A. Contrato coletivo e mercado de trabalho no Brasil. In: MATTOSO, J. et al. $\mathbf{O}$ mundo do trabalho: crise e mudança no final do Século. São Paulo: Scritta, 1994. 183-207 p.

NAVARRO, L. V. Trabalho e trabalhadores do calçado. São Paulo: Editora Expressão Popular, 2006.

OLIVEIRA, C. A. B. Contrato coletivo e relações de trabalho no Brasil. In: MATTOSO, J. et al. O mundo do trabalho: crise e mudança no final do Século. São Paulo: Scritta, 1994.

OLIVEIRA, F. de. Crítica à razão dualista: o ornitorrinco. São Paulo: Boitempo, 2005.

OLIVEIRA, M. A. Tendências recentes das negociações coletivas no Brasil. In: SANTANA, M. A.; RAMALHO, J. R. (Org.). Além da Fábrica. São Paulo: Boitempo, 2003. 271-298 p.

PASTORE, J. A polêmica sobre a terceirização. Revista do Instituto Brasileiro de Siderurgia, nov. 2006. Disponível em: <http://www.josepastore.com.br/artigos/rt/rt_137. htm>. Acesso em: 12 jun. 2015.
PASTORE, J. Terceirização - será que agora vai? O Estado de São Paulo, 24 mar. 2015. Disponível em: <http://economia.estadao.com. br/noticias/geral,terceirizacao-sera-que-agora-vai-imp-,1656521>. Acesso em: 12 jun. 2015.

POCHMANN, M. Trabalho sob fogo cruzado. São Paulo: Contexto, 2002.

POLANYI, K. A grande Transformação: as origens de nossa época. São Paulo: Editora Campus, 1980

PORTES, A.; CASTELLS, M. World underneath: the origins, dynamics, and effects of the informal economy. In: PORTES, A.; CASTELLS, M.; BENTON, L. (Org.). The Informal Economy. Baltimore and London: The John Hopkins University Press, 1989. 11-34 p.

PRIETO, C. Empleo en Europa: transformaciones, tendencias y lógicas. Un análisis comparativo. In: PRIETO, C. (Org.). La crisis del empleo en Europa. Alzira: Germânia, 1999a. v. 1. 9-36 p.

PRIETO, C. Crisis del empleo: Crisis del orden social? In: MIGUÉLEZ, F.; PRIETO, C. (Dir.). Las relaciones de empleo en España. Madrid: Siglo XXI, 1999b. 529-548 p.

PRZEWORSKI, A. Capitalism and social democracy. Paris: Cambridge University Press, 1985.

SANTANA, M. A.; RAMALHO, J. R. Além da fábrica: trabalhadores, sindicatos e a nova questão social. São Paulo: Boitempo, 2003.

SARATT, N.; SILVEIRA, A. D.; MORAES, R. P. Gestão plena da terceirização: o diferencial estratégico. Rio de Janeiro: Qualitymark, 2008.

SENNETT, R. A corrosão do caráter: consequências pessoais do trabalho no novo capitalismo. Rio de Janeiro: Record, 1999.

SILVA. J. B. A face privada de um banco público: os experimentos flexíveis no Banco do Brasil. In: ANTUNES, R. (Org.). Riqueza e Miséria do trabalho no Brasil. São Paulo: Boitempo, 2006. 207-236 p.

SILVA, L. M.. Mercado de trabalho ontem e hoje: informalidade e empregabilidade como categorias de entendimento. In: SANTANA, M. A.; RAMALHO, J. R. (Org.). Além da Fábrica: sindicatos, trabalhadores e a nova questão social. São Paulo: Boitempo, 2003. 140-178 p.

STANFORD, J.; VOSKO, L. Regulating Work and Income. In: STANFORD, J.; VOSKO, L. (Eds.). Challenging the Market: The Struggle to Regulate Work and Income. Montreal: McGill-Queen's University Press, capítulo 1, 2004

THÉBAUD-MONY, A.; DRUCK, G. Terceirização: a erosão dos direitos dos trabalhadores na França e no Brasil. In: DRUCK, G.; FRANCO, T. (Org.). A perda da razão social do trabalho. São Paulo: Boitempo, 2007. 23-58 p

WACQUANT, L. As prisões da miséria. Rio de Janeiro: Jorge Zahar, 2001.

Márcia da Silva Costa

Doutora em Sociologia pelo Instituto Universitário de Pesquisa do Rio de Janeiro - IUPERJ; Professor associado da Universidade Federal da Paraíba. E-mail: marciakosta@hotmail.com. 